\title{
STALIŠČA STARŠEV NA NOTRANJSKEM IN POGLAVITNI MOTIVACIJSKI DEJAVNIKI ZA VKLJUČITEV OTROK V PROGRAME ZGODNJEGA UČENJA TUJEGA JEZIKA PRED OTROKOVIM DEVETIM LETOM STAROSTI
}

\section{UVOD}

Kljub številnim argumentom strokovnjakov, s področij razvojne psihologije, nevropsihologije, antropologije in pedagogike, ZA znižanje starosti tradicionalnega začetka učenja tujih jezikov, otroci v Sloveniji pričnejo $\mathrm{z}$ učenjem tujega jezika $\mathrm{v}$ začetku druge triade osnovne šole, torej v četrtem razredu, pri osmih oz. devetih letih (Brumen 2003: 10 - 11). Običajno je to angleščina, torej jezik, ki je močno prisoten $\mathrm{v}$ okolju. Nekateri starši svojim otrokom pred formalnim začetkom učenja tujega jezika sami nudijo učenje tujega jezika v različnih oblikah, $v$ domačem okolju, $\mathrm{z}$ vključevanjem otrok $\mathrm{v}$ tečaje tujih jezikov, $\mathrm{k}$ interesnim dejavnostim $\mathrm{v}$ šoli, z vključevanjem otrok v izobraževalne ustanove s tujim učnim jezikom, ostali pa na to niti ne pomislijo. Namen raziskave je ugotoviti seznanjenost in odnos staršev na Notranjskem do tega procesa, ter kateri so (de)motivacijski vzroki za vključitev njihovih otrok $\mathrm{v}$ ta proces.

$\mathrm{V}$ prispevku smo kot zgodnje učenje tujega jezika opredelili učenje tujega jezika pred formalnim začetkom $v 4$. razredu osnovne šole - razdeljeno na predšolsko stopnjo (vrtec) in na prvo triado (1., 2. in 3. razred osnovne šole), kar bomo poimenovali tudi učenje tujega jezika $v$ otroštvu.

$\mathrm{V}$ prispevku zaradi praktičnosti navajamo le moške oblike akterjev, kjer pa so zajete tudi osebe ženskega spola. Večkrat uporabljamo kratico TJ, kar pomeni tuji jezik ali tuji jeziki, kar je razvidno iz konteksta.

\section{TEORETIČNA IZHODIŠČA}

Raziskovalci s področij, ki se kakorkoli ukvarjajo $z$ učenjem in poučevanjem tujih jezikov navajajo, da je za učinkovit proces učenja in poučevanja tujega jezika pomembno, da je neprekinjeno, $z$ malo povečanim vnosom od obstoječega znanja (Krashen 1982, McKay 2005, Pinter 2006: 11 - 12), da se odvija sistematično, s pomočjo odraslega (npr. učitelja, starša ali sorojenca), ki ima več znanja kot učenec (Pinter 2006: 11 - 12), o čemer govori teorija Leva Vigotskega, o socialnem konstruktivizmu. Zorman (2008: 244) ugotavlja, da je za slušno 
razločevanje glasov ključen »neposreden stik s sogovorcem in otrokova aktivna vloga $\mathrm{v}$ interakciji $\mathrm{z}$ njim, medtem ko učenje tujega jezika $\mathrm{v}$ pasivni poslušalni vlogi nima nobenega učinka«.

Brumen (2008: 792-802) opozarja na učiteljev pristop k zgodnjemu poučevanju: »Treba je spremeniti koncept poučevanja na predšolski in nižji stopnji osnovne šole, saj učitelji vse prevečkrat poučujejo tako, kot da so učenci le pomanjšani starejši učenci/odrasli, pozabljajo pa, da se miselni svet in nasploh svet petošolca in petletnika zelo razlikujeta«. Da bi se postopoma otresli tradicionalnih didaktičnih konceptov poučevanja tujega jezika in da bi uresničili težnjo Evropske skupnosti o trijezičnih prebivalcih Evrope, Brumen vidi nujnost v urjenju učiteljev, ki bodo sledili novim trendom, pristopom in metodam zgodnjega poučevanja in $\mathrm{v}$ uvedbi tujega jezika $\mathrm{v}$ prvi razred osnovne šole ali celo na predšolsko stopnjo in sicer kot govorno srečanje $\mathrm{z}$ jezikom.

\subsection{Prednosti}

Tako kot izsledki večine tujih raziskav, tudi slovenski strokovnjaki (Brumen, Čok, Dagarin Fojkar, Pižorn) navajajo pomembnost zgodnjega učenja TJ. Brumen (2003: 12-47 in 2009: 68-69) navaja ugotovitve raziskav številnih strokovnjakov, ki potrjujejo prednosti in potrebe po zgodnjem učenju TJ. Te prednosti so: na področju fonetike se otrok zelo približa rojenim govorcem $v$ izgovarjavi, melodiji in ritmu; nedokončana lateralizacija možganov otrokom nekje pred puberteto omogoča bolj naravno razvijanje tujega jezika; pri merjenju inteligenčnega količnika in pri drugih testih so dvojezični otroci uspešnejši in imajo boljše učne rezultate; tujemu jeziku izpostavljeni otroci se lažje učijo dodatnih tujih jezikov, lažje rešujejo probleme, boljše sklepajo, so bolj kreativni, kažejo boljši kognitivni razvoj in divergentno mišljenje, imajo višjo samopodobo, razvijejo sposobnost medkulturnega pluralizma in spoštovanje drugih kultur in ljudi, načeloma zgodnja izpostavljenost tujemu jeziku ne ovira razvoja prvega, ampak spodbuja in povečuje njegove sposobnosti učenja materinščine.

\subsection{Pristopi k zgodnjemu poučevanju}

Zorman (2008: 244) navaja, da že s kratkim stikom s TJ upočasnimo ali celo izničimo zmanjševanje sposobnosti slušnega razločevanja $v$ tem jeziku, ki je značilna za dojenčke od šest do dvanajst mesecev, oz. v odsotnosti tujega jezika zelo napreduje po devetem mesecu, kljub temu je razvoj slušnega razločevanja v prvih letih otrokovega življenja zelo intenziven.

Pinter (2006: 29-30) pravi, da so mlajši učenci bolj sproščeni kot starejši, niso zadržani in lahko posvetijo več časa novemu jeziku. Ker jezika ne analizirajo kot odrasli, se osnovnih komunikacijskih fraz naučijo v vsakdanjih situacijah v svojem okolju. Seveda se z zgodnjim začetkom učenja čas učenja podaljša, več je vnosa jezika, dolgotrajnejša je izpostavljenost tujemu jeziku. Če povzamem Brumnovo, ki utemeljuje, da čim zgodnejši stik s TJ otroku omogoča hitrejše in lažje učenje, imajo predšolski otroci prednost pri učenju TJ že zaradi razvojne stopnje, ki jim omogoča radovedno in dovzetno 
raziskovanje, spontanost, naravnost, sproščenost in željo spoznati čim več novega (Brumen 2009: 68). Tako kot Krashen (1982), Skela in Čok (1999), Pinter (2006) in Brumen $(2006,2011)$ zagovarjajo, da je na zgodnji stopnji poučevanja TJ učinkovit na dejavnostih temelječ pristop, saj se predšolski otroci in učenci v prvem triletju osnovne šole jezika učijo kot celote, za sporočanjske namene, s ciljem razumeti in podati informacijo, torej se ne učijo o jeziku. Kot trdi Krashen (1982: 10), je usvajanje jezika (nasproti učenju) podzavesten proces, tisti, ki ga usvajajo, se običajno tega ne zavedajo, zavedajo se le, da jezik uporabljajo za komunikacijo.

Najbolje je, da se učenje TJ prepleta z igralnimi dejavnostmi, pri katerih sodeluje celotna osebnost in ki spodbujajo hotenje učenca, da se uči tujega jezika, pri čemer je pomembno pozitivno in prijetno vzdušje v razredu (Skela in Čok 1999: 189, McKay 2005: 6, Pinter 2006: 37-39, Brumen 2008: 793, Brumen 2009: 68). Učitelj mora vedeti, da je motivacija za učenje TJ pri majhnih otrocih predvsem na afekt-psihološkem področju, torej lahko pri učenju izkoristi otrokovo zmožnost prevzemanja različnih vlog in dejstvo, da brez predsodkov sprejema nove učne situacije. Po drugi strani pa učitelj pri mlajših otrocih lahko za motivacijo izkoristi otrokovo čustveno navezanost, ki jo posameznik goji do učitelja in tako navduši za učenje tujega jezika (Brumen 2009: 68, Pinter 2006: 37). McKay (2005: 6) pravi, da se učenec z znanjem trudi ugajati učitelju. Da ne smemo zanemarjati čustvenega elementa (Brumen 2005: 793) potrjujejo tudi rezultati raziskav v Veliki Britaniji in na Nizozemskem, ki kažejo, da se pojmovanja učenja tesno povezujejo s pristopi in strategijami s katerimi pristopamo $\mathrm{k}$ učenju, $\mathrm{z}$ učno motivacijo, s čustvenim odnosom in tudi $\mathrm{z}$ učnimi rezultati (Marentič Požarnik 1995: 10).

Dagarin Fojkar (2009: 173) ugotavlja, da v državah, kjer je že utečeno zgodnje poučevanje tujih jezikov, »veliko učiteljev pri pouku uporablja pesmi, rime, gibalne dejavnosti, pravljice in igre ter vključuje elemente medkulturnega in medjezikovnega uzaveščanja«. Te ugotovitve potrjujejo rezultati empirične raziskave v slovenskem prostoru, ki kažejo da se učenci v prvem triletju v osnovni šoli na splošno radi učijo TJ in da pri pouku TJ razvijajo občutek učne kompetentnosti oz. da pridobivajo samopodobo na področju učenja TJ (Juriševič 2009: 98, 107). Raziskava je pokazala, da so mlajši učenci za učenje TJ bolj notranje kot zunanje motivirani, saj se večina anketiranih učencev TJ uči zaradi njegove uporabne vrednosti (67 \%), občutno manj (11 \%) pa zato, da bi zadovoljili svoje starše. Pa vendar so straši tisti, ki se odločijo, ali bodo otroka vključili v zgodnje poučevanje tujega jezika ali ne.

\subsection{Kritično obdobje}

Glede na izsledke raziskav na področju človeških možganov, ki jih navaja Brumen (Brumen 2009: 65-66), bi bilo pričakovati, z nekoliko pretiravanja, da se bodo gruče malčkov izmenjevale v učilnicah tujih jezikov. Pa ni tako. Kljub dejstvu, da otroški možgani zorijo do konca pubertete in se potem lateralizacija leve in desne možganske polovice nekako zaključi, kar pomeni, da si v tem obdobju otrok izgrajuje nevronske povezave v možganih, kar lahko z vsestranskim spodbujanjem 
sinaps optimalizira izgrajeno mrežo (Brumen 2009: 66), otrokom $v$ vrtcu in v prvi triadi osnovne šole še vedno ni zagotovljeno učenje tujega jezika.

Marjanovič Umek (2009: 77) glede kritičnega obdobja navaja opredelitve raziskovalcev različnih strok, ki kažejo, da je čas primeren za začetek učenja TJ vsekakor pred puberteto, saj je povezan z biološkimi in nevrološkimi značilnostmi in tudi s socialnimi dejavniki. Večina navaja kot najustreznejše obdobje za začetek učenja TJ obdobje od tretjega do četrtega leta proti sedmemu in osmemu letu, pri čemer nekateri strokovnjaki poudarjajo, da različne jezikovne zmožnosti lažje pridobimo v različnih kritičnih obdobjih (Marjanovič Umek 2009: 75): »Gre za pozitivni učinek na otrokov splošni spoznavni razvoj, saj spodbuja divergentnost mišljenja, omogoča metajezikovno zavedanje in zvišuje zmožnost jezikovne analize in jezikovne fluentnosti (otrok izbira različne besede v lastnem besedišču), spodbuja razvoj socialne kognicije, vpliva na pozitivno pojmovanje samega sebe in pogostejše ter kakovostnejše vzpostavljanje novih socialnih interakcij«.

\section{OBSTOJEČE STANJE ZGODNJEGA POUČEVANJA TUJEGA JEZIKA V SLOVENIJI}

Iz podatkov, ki jih navaja Dagarin Fojkar, je v šolskem letu 2007/08 skoraj 68 \% osnovnih šol v Sloveniji v prvi triadi devetletke, ko učenje tujega jezika še ni obvezno, ponudilo možnost učenja angleščine (v obliki interesne dejavnosti ali tečaja) in skoraj 30 \% vseh šol je ponudilo učencem učenje nemščine. Prav tako pogosto je fakultativno učenje tujih jezikov v vrtcih. $V$ istem obdobju je skoraj $54 \%$ vrtcev v Sloveniji ponudilo učenje tujega jezika (Dagarin Fojkar 2009: 157).

Kljub privatnim oblikam poučevanja izven predšolskega in šolskega sistema je očitno, da še vedno ostajajo otroci, ki jim ta možnost ni ponujena. »Trenutno stanje v Sloveniji je namreč kaotično, saj se zgodnje učenje pojavlja v različnih oblikah in se začne na različnih stopnjah" (Dagarin Fojkar 2009: 156). Na tem mestu se pojavi vprašanje, zakaj nimajo vsi enakih možnosti za učenje, torej tudi za razvoj? Zdi se, da bi razloge za to vrzel lahko iskali v nespodbudnem okolju in tudi v socialno ekonomskem položaju družine. Marjanovič Umek (2009: 7778) pred čimprejšnjim vključevanjem otrok v usvajanje tujega jezika izpostavlja pomen neprekinjenega poučevanja in učenja tujega jezika, kot je že zgoraj omenjeno, in opozarja na nujnost izdelave celovitega koncepta učenja in poučevanja tujega jezika ali več njih v izobraževalnem sistemu.

Brumen (2011: 721) navaja rezultate raziskav o učenju in poučevanju TJ, ki so bile narejene v Slovenskih vrtcih v letih 1998, 2001 in 2008 pod vodstvom Zavoda RS za šolstvo, ki kažejo, da so bili plačljivi tečaji tujih jezikov, kot dodatna ponudba vrtca $z$ zunanjimi izvajalci, organizirani $v$ več kot polovici slovenskih vrtcev za starostne skupine od 4 do 6 let, enkrat ali dvakrat tedensko po 35 ali 45 minut. Najpogosteje je bila to angleščina, ob državnih mejah z Avstrijo in Italijo pa nemščina oz. italijanščina. Rezultati kažejo, da učenje TJ slovenskih vrtcih v zadnjih dvajsetih letih ni bilo koordinirano, torej da je bilo urejeno na različne 
načine, največkrat na pobudo staršev in $\mathrm{z}$ različno usposobljenimi strokovnjaki. Ugotovljeno je bilo tudi, da učne metode in pristopi pogosto niso bili prilagojeni predšolskim otrokom. Kot navaja avtorica, je problem socialne neenakosti, ki se je pojavljala v tem procesu, Ministrstvo za šolstvo in šport leta 2007 rešilo s prepovedjo vključevanja plačljivih dodatnih aktivnosti v času, ko se izvaja vrtčevski program. V tem obdobju je bilo vloženega veliko truda, da bi učenje tujih jezikov postalo del vrtčevskega kurikula.

Brumen (2011: 722-723) nadalje navaja rezultate raziskave, ki je bila opravljena na Štajerskem med letoma 2008 in 2009 pod okriljem Zavoda RS za šolstvo. Vključenih je bilo 120 otrok iz sedmih vrtcev in 11 posebej visoko usposobljenih učiteljic za zgodnje poučevanje tujega jezika, ki so preizkušale nove didaktične metode in gradiva. Otroci so se tujega jezika učili z aktivno udeležbo na konkretnih izkušnjah. Vsebine so se nanašale na otrokovo naravno in socialno okolje (npr. jaz in moja družina, štirje letni časi in vreme, promet in vozila, narava in hišni ljubljenčki). Uporabljali so različne metode in učne pripomočke, se učili preko gibalnih iger, plesa, petja, zgodbic, dramatizacije, socialnih iger, igre vlog, idr., kar je pripomoglo k motivaciji otrok za učenje TJ. Brumen (2011: 730) zaključuje: »Rezultati nas pripeljejo do zaključka, da otroci ne samo da preko igre in prijetnih aktivnosti dojemajo učenje TJ kot nekaj zabavnega, ampak jim to daje intelektualni izziv in občutek zadovoljstva z osebnimi dosežki. Učitelji bi morali z dobrim in razumevajočim poučevanjem razvijati in ohranjati notranjo motivacijo pri otrocih tako, da ostane notranjega izvora tudi pri nadaljnjem učenju tujih jezikov.«

Dagarin Fojkar (2009) je preučila organizacijo poučevanja tujih jezikov na zgodnji stopnji v nekaterih državah z bogatimi izkušnjami na tem področju $z$ namenom, da bi bili slovenski snovalci programov seznanjeni s prednostmi in slabostmi določenih že uveljavljenih modelov in metod. Izpostavlja dolgoletne izkušnje z zgodnjim učenjem TJ v Kanadi, kjer so uveljavljeni trije modeli jezikovne kopeli (Dagarin Fojkar 2009: 164), opisuje pa tudi modele poučevanja v Avstriji, na Hrvaškem in v Italiji in sklepa, da so si v osnovi vsi podobni, tako jezikovna kopel, kot integrirano poučevanje, »zasidranje« ter vsebinsko in celostno učenje, predvsem glede izbire tem, pa tudi glede povezovanja poučevanja tujih jezikov z drugimi predmeti. Ugotavlja tudi, da je v Evropi in drugod po svetu formalno zgodnje učenje tujih jezikov $\mathrm{v}$ porastu in da je v osnovni šoli otrokom ponujenih vedno več tujih jezikov (Dagarin Fojkar 2006: 157). To zadnje, torej v okviru celotnega šolskega sistema (vključno s predšolsko dobo) ponuditi možnost za vseživljenjsko razvijanje večjezičnosti, spodbuja tudi Skupni evropski jezikovni okvir za učenje, poučevanje in vrednotenje jezikov (Cadre européen commun de référence pour les langues: apprendre, enseigner, évaluer 2000: 11). V strokovni javnosti se izpostavlja kot uspešen model zgodnje poučevanje angleščine na Hrvaškem, kjer je začetek učenja tujih jezikov pomaknjen v prvi razred osnovne šole. Kot pomembnejši dejavnik za uspeh hrvaški učitelji izpostavljajo urnik, in sicer predlagajo eno šolsko uro učenja petkrat na teden. McKay (2005: 6) za mlajše učence predlaga časovno omejitev ob začetku učenja tujega jezika na 10 do 15 minut dnevno, ker nimajo sposobnosti daljše koncentracije na določeno dejavnost in ker naloge lahko ne dokončajo zato, ker se jim 
zdi pretežka. S tem, ko se otrokova sposobnost razmišljanja razvija (od petega do dvanajstega leta), se sorazmerno podaljšuje čas učenja. Brumen (2008: 793) za slovenski prostor predlaga isto časovno razporeditev poučevanja in pojasnjuje, da bi bili učenci s tako ureditvijo dnevno v stiku z jezikom, torej intenzivneje, s čimer bi znižali stopnjo pozabljanja.

\section{CILJI RAZISKAVE}

V raziskavi nas zanimajo predvsem ključni motivacijski dejavniki staršev pri odločanju staršev za (ne)vključitev otrok v programe zgodnje poučevanje tujega jezika, bodisi v vrtčevski ali šolski situaciji, ki običajno potekajo v obliki (plačljivih) tečajev, bodisi v domačem okolju, kjer običajno starš svojega otroka sistematično poučuje tuji jezik ali pa starša $z$ otrokom govorita vsak svoj materni jezik.

Ker smo predvidevali, da na motivacijo staršev vplivajo tudi ozaveščenost oz. njihova stališča o sodobnih izhodiščih na področju zgodnjega učenja in poučevanja tujih jezikov, seznanjenost s strokovno literaturo oz. želja po boljšem poznavanju te teme in poznavanje aktualnega stanja $\mathrm{v}$ Sloveniji in $\mathrm{v}$ tujini na področju zgodnjega poučevanja tujih jezikov, smo $\mathrm{z}$ anketnim vprašalnikom pridobili tudi te podatke.

\section{METODOLOGIJA}

\subsection{Vzorec}

V raziskavo so bili vključeni naključno izbrani starši otrok, ki so vključeni v vrtce $v$ Notranjski regiji ali obiskujejo prvo triado $v$ kateri izmed osnovnih šol na Notranjskem. Anketni vprašalniki so bili poslani na devet osnovnih šol in $\mathrm{v}$ šest vrtcev.

Vrnjenih je bilo 135 anketnih vprašalnikov, ki smo jih pri analizi razdelili na tri skupine in sicer glede na vključitev otrok v družini: vrtec (20), vrtec in prva triada osnovne šole (66), prva triada osnovne šole (49).

\subsection{Instrumenti}

Za raziskavo je bil oblikovan anketni vprašalnik, razdeljen na pet delov. V prvem delu smo pridobili osnovne demografske podatke, $v$ drugem seznanjenost staršev s strokovno literaturo na področju zgodnjega poučevanja TJ in njihove želje po boljšem poznavanju te tematike. $V$ tretjem delu smo ugotavljali poznavanje aktualnega stanja na področju poučevanja tujih jezikov $\mathrm{v}$ tujih in $\mathrm{v}$ slovenskih formalnih izobraževalnih ustanovah, ki jih obiskujejo otroci pred 9. oz. 10. letom starosti. $V$ četrtem delu smo pridobivali podatke o ozaveščenosti staršev oz. njihova stališča o sodobnih izhodiščih na področju zgodnjega učenja in poučevanja tujih jezikov. V petem delu anketnega vprašalnika nas je zanimalo, kateri so ključni motivacijski dejavniki pri odločanju staršev za (ne)vključitev otrok v dejavnosti učenja TJ na predšolski stopnji in /ali v prvem triletju osnovne šole. 
Vprašalnik sledi vsem merskim karakteristikam. Vsebinska veljavnost je bila zagotovljena s pregledom dveh strokovnjakinj s področja zgodnjega poučevanja tujih jezikov.

\subsection{Postopek}

Anketni vprašalnik so izpolnjevali starši individualno, nevodeno. Namen zbiranja podatkov je bil naveden $\mathrm{v}$ uvodnem delu anketnega vprašalnika, prav tako telefonski in spletni kontakt izvajalke raziskave. $Z$ namenom raziskave so bili seznanjeni ravnatelji vrtcev in osnovnih šol, da so lahko posredovali vse potrebne informacije vzgojiteljem in učiteljem, ki so naključno razdelili anketne vprašalnike med starše. Starši so anketne vprašalnike vračali vzgojiteljem ali učiteljem v za to posebej pripravljeno mapo, da je bila zagotovljena anonimnost.

\section{REZULTATI IN INTERPRETACIJA}

\subsection{Struktura anketirancev}

$\mathrm{Na}$ anketni vprašalnik so odgovarjali naključno izbrani starši otrok, ki na Notranjskem obiskujejo vrtec ali prvo triado osnovne šole. Žensk $(87,4 \%)$ je bilo več kot moških (11,9\%). Najpogostejša starost anketirancev se je gibala med 36 in 45 leti $(49,6 \%)$, nekoliko manj (46,7\%) je bilo starih med 27 in 35 let, mlajših (1,5\%) ali starejših (2,2\%). Najpogostejša izobrazba anketirancev je končana srednja šola (33,3\%), 26,7\% staršev ima končano univerzitetno izobrazbo, 25,2 \% višjo ali visokošolsko izobrazbo, 8,1 \% končano poklicno šolo, 4,4 \% jih ima magisterij ali doktorat in $2,2 \%$ končano osnovno šolo. Več kot polovica $(51,1 \%)$ anketiranih staršev ima v družini dva otroka, 31,1 \% tri otroke, 10,4 \% enega otroka, $4,4 \%$ anketirancev ima 4 otroke, $2,2 \%$ pet otrok in 1 starš $(0,7 \%)$ s šestimi otroki.

$\mathrm{Na}$ vprašanje, ali so dvo- ali več-jezični, jih $51,9 \%$ ocenjuje, da so enojezični, ostalih 48,1\% staršev odgovarja pritrdilno. Izmed teh zadnjih večina aktivno obvlada angleški jezik $(39,2 \%)$, hrvaški jezik 11,8\% anketirancev, nemščino in italijanščino $6,6 \%$, manjšina pa srbski jezik, srbohrvaški jezik, bosanski jezik in slovaški jezik. Največ $(42,2 \%)$ se jih je tujega jezika naučilo v formalnem izobraževanju (v osnovni šoli in/ali v srednji šoli in/ali na fakulteti), veliko manj $(8,1 \%)$ na tečajih tujih jezikov, $(5,1 \%)$ v službi ali zaradi potreb službe, nekateri $(3,7 \%)$ so priseljeni v Slovenijo in je tuji jezik njihov materni jezik. Ostali navajajo: $v$ času bivanja $\mathrm{v}$ tujini in $\mathrm{s}$ pomočjo televizijskih programov $(2,2 \%)$, posamezniki pa preko pogostega druženja s tujci, samostojno doma, v prostem času, $v$ času potovanj, zaradi bližine meje.

V Resoluciji Sveta EU o evropski strategiji za večjezičnost (2008) je zapisano, da je potrebno evropskim državljanom omogočiti, da bodo znali komunicirati $\mathrm{v}$ maternem jeziku in še dveh drugih tujih jezikih. Za dosego tega cilja bo glede na zgornje rezultate potrebno vložiti še veliko truda. Zato je še toliko bolj pomembno ljudem predstaviti argumente za učenje tujih jezikov. Če si sposodim Finkenstaedtovo in Schröderjevo (v Brumen 2003: 17) misel: »Prihodnosti bomo 
kos le $\mathrm{z}$ negovanjem prvega, maternega jezika in $\mathrm{z}$ dovolj zgodnjim intenzivnim učenjem tujih jezikov. Evropa potrebuje jezikovno deljeno družbo.«

\subsection{Drugi del anketnega vprašalnika}

Rezultati drugega dela raziskave, ki ugotavlja, ali se anketiranci izobražujejo na področju zgodnjega učenja TJ, kažejo, da naključno izbrani starši na Notranjskem v veliki večni $(91,1 \%)$ niso še nikoli poslušali predavanja na temo zgodnje poučevanje in učenje TJ, kjer bi se seznanili z vlogo in pomenom učenja TJ v zgodnjem obdobju, nekoliko manj jih ni bilo nikoli povabljenih na predavanje. Slaba polovica anketirancev odgovarja, da so prebrali znanstveni, strokovni ali časopisni članek na temo zgodnje učenje TJ, kar kaže na potrebo po izobraževanju. To dokazuje tudi odgovor slabih $73 \%$ staršev, ki si želijo zvedeti več na to temo. Slabi polovici vprašanih se zdi smiselno pridobiti tovrstne informacije $\mathrm{v}$ času vpisa $\mathrm{v}$ vrtec oz. $\mathrm{v}$ šolo, četrtina staršev meni, da je najbolje to izvedeti na neobveznih predavanjih v organizaciji vrtca ali šole, nekaterim bi ustrezalo že ob rojstvu otroka dobiti brošuro z osnovnimi podatki in uporabnimi kontakti (npr. spletne strani, kjer so dostopni članki na temo učenje tujih jezikov).

\subsection{Tretji del anketnega vprašalnika}

$\mathrm{V}$ tretjem delu raziskave, ki ugotavlja poznavanje razmer na področju poučevanja tujih jezikov, rezultati kažejo, da se $43 \%$ staršev zaveda, da ne poznajo sistema učenja TJ v Sloveniji, dobrih $30 \%$ meni, da ni urejen, $\mathrm{k}$ tem prištejemo še slabih $10 \%$ staršev, ki se sploh ne strinjajo z obstoječo strukturo, le dobrih $13 \%$ ne bi ničesar spreminjali. Veliko anketiranih staršev ne pozna trenutnih razmer na področju zgodnjega poučevanja tujih jezikov v Sloveniji. Slabih 84 \% vprašanih ne pozna sistema poučevanja TJ v drugih evropskih državah, kar jim onemogoča primerjavo ureditve zgodnjega učenja $\mathrm{TJ} v$ tujih izobraževalnih sistemov $\mathrm{z}$ domačo, kot tudi primerjavo šolanja svojih otrok s šolanjem slovenskih sovrstnikov. V nasprotnem primeru bi verjetno zahtevali spremembe, saj se od slabe polovice staršev $(48,1 \%)$, ki so dvojezični in se zavedajo pomenov znanja tujega jezika, le malo manj otrok $(45,9 \%)$ uči tujega jezika v vrtcu ali v prvi triadi osnovne šole. Od teh je $12,6 \%$ otrok dvojezičnih iz različnih vzrokov.

Najpogosteje zaradi različnih maternih jezikov otrokovih staršev, veliko manj primerov dvojezičnih otrok je zato, ker anketiranec dobro obvlada tuji jezik in se zato s svojim otrokom redno pogovarja v ciljnem tujem jeziku. So primeri, ko materni jezik otrokovih starih staršev ni enak maternemu jeziku anketiranca, ali pa gre za osamele primere (npr. priselitev v Slovenijo, večletno intenzivno obiskovanje tečaja TJ).

19,3 \% otrok starši sami sistematično poučujejo TJ, ki ga tekoče govorijo. Dobra polovica $(51,1 \%)$ staršev navaja, da je njihov otrok sam izrazil željo, da bi se učil TJ. Nekoliko manj $(45,2 \%)$ jih navaja, da so se za zgodnje učenje TJ odločili sami ali s svojim partnerjem. S trditvijo »Sistem naj ostane urejen tako kot je: začetek učenja angleščine v 4. razredu OŠ, v 7. razredu drugi (in tretji) tuji jezik.«, se ne strinja $36,3 \%$ staršev, tem lahko dodamo še tiste $(7,4 \%)$, ki se sploh ne strinjajo, 
torej 43,7\%. Kar 18,5\% ne ve kaj bi bilo dobro. Na drugi strani pa se s trditvijo strinja $23,7 \%$ in zelo strinja $8,1 \%$, torej $31,8 \%$.

\section{Graf 1}

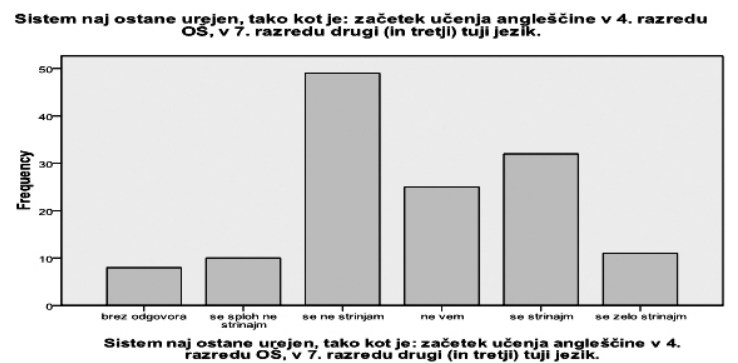

Analiza kontrolnega vprašanja kaže, da se dobra polovica $(52,6 \%)$ staršev zaveda neenakosti otrok v Sloveniji kar zadeva enake možnosti za zgodnje učenje TJ. Slabih 30\% odgovarja $\mathrm{z}$ »ne vem «, s trditvijo se bolj ali manj strinja $14 \%$ staršev.

\section{4 Četrti del vprašalnika}

Četrti del vprašalnika ugotavlja stališča staršev o sodobnih izhodiščih zgodnjega učenja in poučevanja TJ. Glede na prejšnje rezultate o informiranosti staršev bi sklepali, da starši ne bodo veliko vedeli o teoretičnih dognanjih strokovnjakov s področja zgodnjega poučevanja TJ, pa se je v okviru osmih trditev izkazalo, da imajo starši izjemen občutek za to področje izobraževanja.

\section{Graf 2}

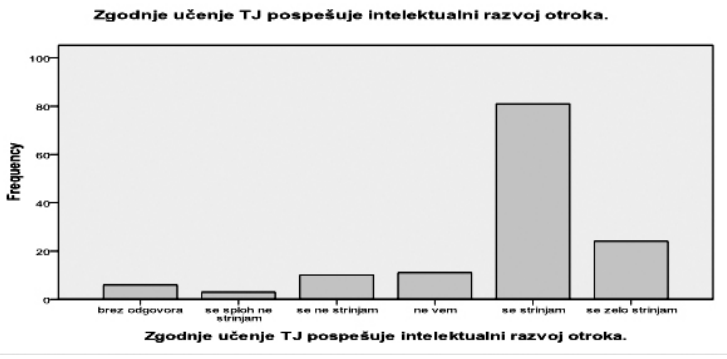

Iz grafa 2 je razvidno, da je dobila največjo podporo trditev »Zgodnje učenje TJ pospešuje intelektualni razvoj otroka.«. 60\% staršev se strinja, 17,8\% je izrazilo svoje prepričanje $z$ opcijo »se zelo strinjam, torej $77,8 \%$. Ta trditev je imela najmanj odgovorov $»$ ne vem $\ll(8,1 \%)$.

S 74,8\% strinjanja sledi trditev »Najvidnejša prednost, ki jo otrok pridobi z zgodnjim učenjem TJ je velika spretnost v govornih sposobnostih: slušne spretnosti, samozavest v govornih situacijah.«, 11,9\% staršev tega ne ve. Na tretjem 
mestu, z 71,9\% strinjanja, starši ocenjujejo, da bi bilo najbolje, če bi usposobljena vzgojiteljica /učiteljica (matična ali gostujoča) otroke poučevala TJ tako, da bi z njimi govorila o vsakdanjih opravilih, da bi jih vključevala v vsakdanje situacije: pri zdravniku, v restavraciji, ...

Po pomembnosti si rezultati sledijo: 67,4\% staršev meni, da je zgodnje učenje TJ (pred puberteto) naravno, neprisiljeno, 15,6 \% meni, da tega ne ve. 58,5\% staršev meni, da uvajanje prvega tujega jezika v zgodnji fazi olajša kasnejše vpeljevanje 2. ali celo 3. TJ. Dobra polovica staršev se ne strinja s trditvijo »Če se otrok istočasno opismenjuje v dveh ali več jezikih, je popolnoma zmeden.«, s čimer se strinja $23 \%$ anketirancev. Polovica jih meni, da se otrok lahko uči dva (ali več) jezika istočasno, $22,9 \%$ se s tem ne strinja in $25,2 \%$ staršev ne vedo ali je to mogoče ali ne. In na zadnjem mestu je trditev »Najbolje bi bilo, če bi usposobljena vzgojiteljica /učiteljica (matična ali gostujoča) otroke poučevala tuji jezik tako, da bi jih naučila najprej abecedo, potem pa besede: barve, živali, oblačila,... s s 47,4\% podpore, $23,7 \%$ nestrinjanja in $25,2 \%$ skeptikov.

\section{Graf 3}

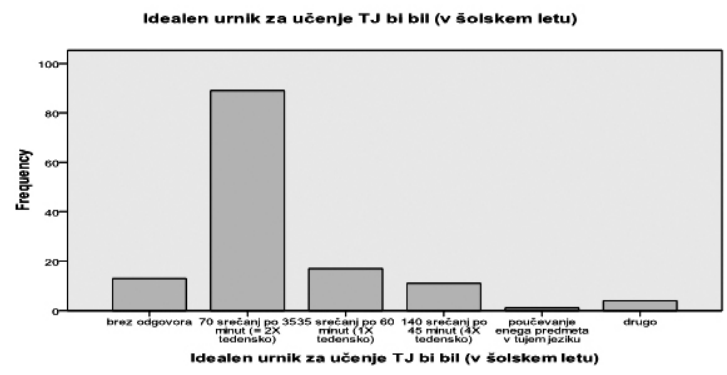

Graf 3 kaže, da se staršem zdi najbolj smiselna tista ureditev urnika, ki je najbolj utečena, tista, ki so je bili tudi oni najpogosteje deležni v času šolanja, torej srečanja dvakrat tedensko, zaradi krajše koncentracije otrok so izbrali časovno omejitev na 35 minut. V rubriki »drugo« trije starši ponujajo boljše predloge in sicer vsak dan po 30 minut, oz. predlagajo krajši čas za dvakrat tedenska srečanja.

Graf 4

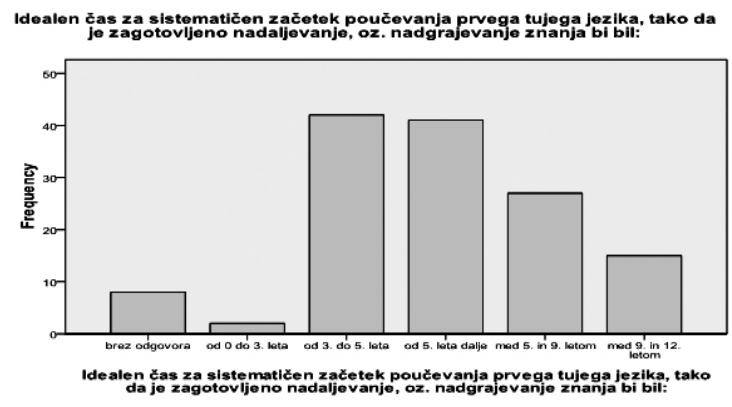


Graf 4 kaže na zelo deljeno mnenje anketiranih staršev glede optimalne starosti za začetek učenja TJ.

Iz rezultatov je razvidno, da se staršem $(90,4 \%)$ zdi najprimernejši jezik za začetek učenja TJ jezik, ki se ga veliko oz. največ sliši v okolju in imamo z njim pogoste stike: splet, mediji (npr. angleščina). Druga izbira (33,3\%) bi bil jezik sosednjih držav (npr. hrvaščina, italijanščina, nemščina, madžarščina). Tretja izbira (24,4\%) bi bil jezik, ki ga govori veliko govorcev na svetu. 14,8\% staršev meni, da je najprimernejši tuji jezik za začetek učenja TJ jezik, ki je povezan z osebnimi interesi (družinske korenine, tradicija znanja tujega jezika v družini,...). Na predzadnjem mestu, 7,4\% staršem se zdijo najprimernejši tisti jeziki, ki se jih ne sliši v okolju, pa so kakorkoli pomembni za zaposlitev, ali predstavljajo razvijajoče se trge, ali so bogat vir literature ipd. (npr. francoščina, ruščina, kitajščina). Vsi anketiranci se strinjajo, da so najbolj neprimerni za zgodnje učenje TJ eksotični jeziki (npr. kateri od afriških jezikov).

\section{Graf 5}

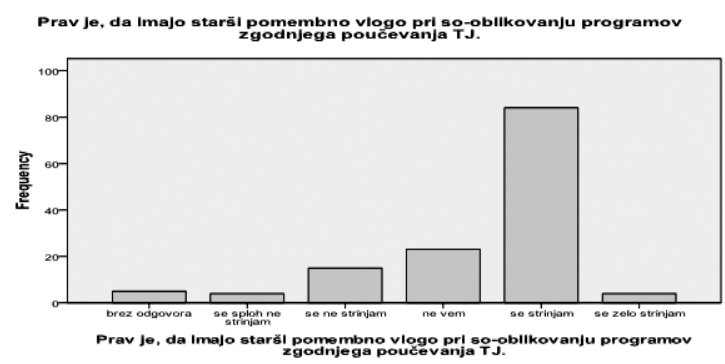

Graf 5 kaže, da si večina $(65,2 \%)$ staršev želi imeti pomembno vlogo pri oblikovanju programov zgodnjega poučevanja TJ, kar je tudi smiselno, saj se spremembe nanašajo na njihove otroke. Vendar bi bilo posledično nujno staršem omogočiti lažji dostop do informacij, denimo zagotoviti boljšo dostopnost do literature (izdelati npr. priročnik za starše s krajšo teoretično obrazložitvijo in $z$ uporabnimi primeri iz priporočene literature), do izobraževanj v obliki predavanj, za kar bi bilo potrebno oblikovati programe za izobraževanje staršev, kjer bi spoznali dognanja strokovnjakov s tega področja, slišali primere dobrih praks, zgodbe dvojezičnih ljudi ipd. Ne nazadnje so tudi sami izrazili potrebo po boljši informiranosti. Sploh se to zdi smiselno za območja, kjer ni velike ponudbe, kjer ni pretiranega oglaševanja za tovrstne dejavnosti, kjer je strnjeno prebivalstvo z nižjo izobrazbeno strukturo in verjetno tudi z nižjimi osebnimi dohodki, ki omejujejo starše, da bi svojim otrokom nudili udeležbo v plačljivih programih. Kar pojasnjujejo tuje in domače raziskave:

Marjanovič Umek (2008: 103-105) navaja rezultate tujih raziskav, da imajo višje izobraženi starši več znanja o značilnostih in načinih spodbujanja otrokovega razvoja, bolj sodelujejo s strokovnimi delavci v vrtcu in $v$ šoli ter svojim otrokom v vseh razvojnih obdobjih ponujajo spodbudnejše okolje za razvoj in učenje; da se govorni razvoj otroka pozitivno povezuje $\mathrm{z}$ izobrazbo mame in $\mathrm{z}$ drugimi 
sociodemografskimi značilnostmi družine; da so mame z višjo izobrazbo izražale zgodnja pričakovanja o sposobnostih svojih dojenčkov in malčkov (menile so, da prej vidi, prej sliši, prej se začne učiti).

Marjanovič Umek in Fekonja Peklaj (2008) opozarjata na pomemben učinek mamine izobrazbe na govorno kompetentnost različno starih malčkov in otrok v zgodnjem otroštvu. Slovenska raziskava, ki so jo opravile Marjanovič Umek, Fekonja in Bajc (2006 v Marjanovič Umek in Fekonja Peklaj: 106) je pokazala, da se intelektualne sposobnosti, govorna kompetentnost in pripravljenost za šolo šestletnih otrok pomembno in zmerno povezujejo $\mathrm{z}$ izobrazbo mame in očeta.

$S$ tako vseslovensko akcijo bi zmanjšali procent »ne vem« odgovorov, pomagali bi dvojezičnim ali večjezičnim staršem, ki sami poučujejo svoje otroke in dvignili bi zavest o pomembnosti znanja TJ, kar bi pripomoglo k boljšemu medsebojnemu razumevanju, razumevanju drugih kultur in seveda $\mathrm{k}$ spoštovanju svoje jezikovne identitete.

\subsection{Peti del anketnega vprašalnika}

Zadnji del razkriva dvoje: odnos staršev do zgodnjega učenja TJ (na ta vprašanja so odgovarjali vsi sodelujoči starši) in ključne motivacijske dejavnike pri odločanju staršev za (ne)vključitev otrok v dejavnosti učenja TJ na predšolski stopnji in / ali v prvem triletju osnovne šole (na ta vprašanja so odgovarjali starši tistih otrok, ki se učijo tujega jezika oz. tisti, ki bi ga vključili v program zgodnjega učenja TJ, zato je v rezultatih več vprašanj upravičeno ostalo brez odgovora.

\subsubsection{Stališča staršev do vključevanja otrok v programe zgodnjega učenja tujih jezikov}

20 staršev $(14,8 \%)$ od 135 odgovarja, da so odločno proti zgodnjemu učenju TJ in zagovarjajo misel, da morajo otroci imeti otroštvo. Prav toliko jih meni, da predšolski otroci v starosti od 3 do 5 let in otroci prve triade $v$ OŠ dolgoročno nič ne pridobijo z zgodnjim učenjem TJ. 31 (23\%) staršev odgovarja, da na učenje TJ niso niti pomislili, 23 (17\%) jih meni, da mora otrok najprej usvojiti (govorno in pisno) materin jezik in se strinjajo s trditvijo, da je smiselno začeti z učenjem $\mathrm{TJ} v$ 4. razredu OŠ, da otroci ne pomešajo dveh ali več jezikov. $14(10,4 \%)$ jih pravi, da je to zguba časa in denarja in zagovarjajo idejo, da se starejši otroci v istem času naučijo več.

Eden pomembnejših podatkov, ki smo jih pridobili je, da bi kar $43 \%$ staršev svojega otroka vključilo v program zgodnjega učenja TJ, samo v primeru, če bi bil del vrtčevskega ali šolskega programa, ali če bi bil brezplačen. Več kot polovica staršev bi otroke vključila $v$ programe zgodnjega učenja $\mathrm{TJ} v$ primeru, da bi bilo v 4. razredu OŠ zagotovljeno nadaljevanje učenja TJ. Po drugi strani je pa več kot $80 \%$ (od tistih staršev, ki so svojega otroka vpisali v tečaj TJ), to storilo prav zato, ker so želeli da bo njihovemu otroku lažje pri rednem pouku TJ.

Prav posebej nas je zanimalo zadovoljstvo staršev z razpoložljivo ponudbo za učenje TJ. 28,9\% staršev se strinja s trditvijo, da je učenje TJ smiselno, vendar ocenjujejo, da ni ponudbe. $66 \%$ se ne strinja s trditvijo, $4,4 \%$ staršev ni dalo odgovora. 
Medtem ko na trditev »S ponudbo sem zadovoljen / zadovoljna.«, odgovarjajo nekoliko drugače: zadovoljnih je $47.7 \%$, nezadovoljnih pa $40 \%$, ostali $(12,6 \%)$ na vprašanje niso odgovorili.

Če razberemo iz anketnih vprašalnikov, bi starši ponudili svojim otrokom sledeči okvir: učenje jezika, ki se ga veliko oz. največ sliši v okolju in imamo z njim pogoste stike: splet, mediji (npr. angleščina). Predvsem zato ker vejo, da zgodnje učenje pospešuje intelektualni razvoj otroka in da mu bo pridobljeno znanje koristilo. V okviru 70 srečanj po 35 minut oz. 2 krat tedensko, bi bilo najbolje, če bi usposobljena vzgojiteljica /učiteljica (matična ali gostujoča) otroke poučevala TJ tako, da bi z njimi govorila o vsakdanjih opravilih, da bi jih vključevala v vsakdanje situacije: pri zdravniku, $v$ restavraciji,... In samo en starš bi svojemu otroku ponudil poučevanje enega predmeta $v$ tujem jeziku. Na glasovanje bi verjetno dali starost otrok ob vključitvi v učenje tujih jezikov in sicer bi odločali med dvema skupinama: od 3. do 5. leta dalje ali od 5. leta dalje.

Kot navaja Pižorn v spletnem dokumentu (str. 7), obstaja več strokovno oblikovanih modelov (npr. jezikovna kopel, senzibilizacija) za zgodnje učenje in poučevanje tujih jezikov: »Driscoll (1999) ugotavlja, da modelov ni mogoče razvrstiti na črne in bele, na dobre in slabe, temveč jih je potrebno analizirati $v$ luči danih okoliščin (količina in kakovost vnosa dodatnega jezika/ov, usposobljenost učiteljev, učni pripomočki, zunajšolska možnost stika učencev z dodatnim jezikom itn.)«.

\subsubsection{Razlogi za vključitev otrok v program zgodnjega učenja TJ}

Analiza vprašanj, o poglavitnih motivacijskih razlogih za vključitev otrok v program zgodnjega učenja TJ, na katera so odgovarjali samo starši tistih otrok, ki se učijo TJ oz. tisti, ki bi ga želeli vključiti v program zgodnjega učenja TJ, kaže, da je osnova odločitev precej splošna in sicer z željo, da bi otroku pridobljeno znanje koristilo (95\%). Drugi razlog so potovanja v kraje, kjer otroci lahko uporabljajo ta jezik (83\%), tretje mesto (81\%) si delita dva razloga in sicer upanje, da bo otroku mogoče nekoč zaradi tega lažje preživeti v tujini (študij, zaposlitev, iskanje literature, potovanja, ...) in konkreten razlog »Moj otrok je vpisan $v$ tečaj, ker imamo redne stike z govorci ciljnega jezika«. Z 80,4\% pritrdilnih odgovorov je na četrtem mestu naše motivacijske lestvice razvidna skrb staršev. $Z$ vpisom v tečaj so želeli doseči tudi to, da bo njihovemu otroku lažje pri rednem pouku tujega jezika. S petim mestom starši učitelju dodeljujejo zelo pomembno vlogo. Na vprašanje »Moj otrok je vpisan (bi bil vpisan) v tečaj, ker vem, da ga uči zelo dobra učiteljica, ki je jezikovno in didaktično dobro usposobljena za zgodnje poučevanje TJ.«, od 78 odgovorov kar 55 staršev (70,5 \%) odgovarja pritrdilno, le enega starša učiteljeva vloga ne zanima.

Analiza kaže, da je ovira pri vključevanju otrok v učenje TJ tudi plačevanje tečajev. Več kot polovica $(52,5 \%)$ staršev je svojega otroka vključila v tečaj, ker ni preveč drag in samo treh od $78(0,3 \%)$ cena ne zanima. Najbolj deljeno mnenje je bilo pri trditvi »Moj otrok je vpisan v tečaj tujega jezika, da bo razumel risanke, filme in pesmi v tem jeziku. « 49,3 \% staršev odgovarja pritrdilno, 38,9 \% negativno, ostali (11,6 \%) bodisi ne vejo ali jih ne zanima. Slabih $30 \%$ meni, da svojih 
otrok ne znajo sami naučiti TJ, zato to delo raje prepustijo usposobljenim učiteljicam, 65,3 \% staršem to ni bil razlog za vpis otroka v tečaj TJ. 23,3 \% staršev je svojega otroka vpisalo v tečaj TJ tudi zato, ker imajo sorodnike v tujini. Rezultati kažejo, da starši ne vpisujejo otrok v tečaje iz lastne notranje ali integrativne motivacije, npr. ker bi sami naravnost oboževali ciljni jezik, njegovo kulturo ali govorce ampak so njihovi motivi zunanje usmerjeni, so instrumentalni, s čimer lahko pojasnimo veliko zanimanje za angleščino, ki postaja mednarodni jezik, lingva franca. Glede na rezultate socializacija otrok v tem obdobju ni zelo izrazita, saj so le štirje starši $(0,5 \%)$ svojega otroka vpisali v tečaj zato, ker so vpisani vsi otroci iz njegove skupine, oz. sošolci. Ostalim $(87,1 \%)$ to ni bil motivacijski razlog. In na zadnjem, dvanajstem mestu, se je vpliv okolice izkazal za brezpredmetnega. $\mathrm{Na}$ vprašanje »Moj otrok je vpisan v tečaj, ker mi je nekdo tako svetoval.« kar 96,1\% staršev odgovarja $\mathrm{z}$ ne.

\section{SKLEP}

Ko opazujemo otroke pri vsakodnevnih opravilih ali pri igri, brez težav ugotovimo, da so notranje motivirani za aktivnosti, ki jih opravljajo. Prav tako je pri učenju tujega jezika. MacIntyre (1999 v Brumen 2011: 725) pravi, da učenci kažejo prirojeno radovednost za odkrivanje sveta in zato se jim bodo zdele učne izkušnje same po sebi zabavne. Učitelji bi se mogli zavedati svoje naloge, in sicer, da lahko ohranijo otrokovo zanimanje za jezik s pravilno izbiro metodoloških in didaktičnih pristopov, prilagojeno starosti skupine. $V$ raziskavi nas je zanimala vloga staršev $\mathrm{v}$ tem procesu.

Da bi ugotovili kateri so ključni (de)motivacijski dejavniki vključevanja otrok v zgodnje učenje tujih jezikov, smo preverili tudi ozadje: ali se izobražujejo na tem področju (literatura, predavanja), ali poznajo aktualno stanje na tem področju izobraževanja doma in $\mathrm{v}$ tujini, ali so ozaveščeni o sodobnih izhodiščih s področja zgodnjega učenja in poučevanja tujih jezikov in njihova stališča, ter njihove želje in predstave o poteku učenja tujih jezikov.

Brumnova (2011: 730) z raziskavo ugotavlja, da so otroci notranje motivirani za učenje tujega jezika: »Hočejo se učiti, ker uživajo v učnem procesu tujega jezika zaradi procesa samega.« Ugotavljamo, da je več kot polovica $(51,1 \%)$ otrok izrazila željo, da bi se učili tujega jezika in da se 45,9 \% otrok na Notranjskem uči tujega jezika, kar sovpada s 45,2 \% staršev, ki so se za zgodnje učenje tujega jezika odločili sami ali v dogovoru s partnerjem. Ta procent približno sovpada s procentom tistih staršev (47,4 \%), ki so s ponudbo zadovoljni. 28,9 \% se zdi, da je zgodnje učenje tujega jezika smiselno, vendar da ni ponudbe. Seveda so starši tisti, ki odločajo s katerimi dejavnostmi se bo ukvarjal otrok v prostem času, zato je nujno začeti starše ozaveščati o smiselnosti zgodnega učenja tujega jezika, saj so sami izrazili željo po boljši informiranosti. Ugotavljamo, da čeprav se starši ne udeležujejo predavanj in ne poznajo sistema zgodnjega učenja tujih jezikov v Sloveniji in v tujini, imajo dober občutek za to, kaj je dobro za njihovega otroka in za njegov razvoj, saj se večina strinja $z$ najnovejšimi dognanji strokovnjakov. 
Še najlažje pa bi bilo, da bi znižali starost začetka učenja tujega jezika v obveznem osnovnošolskem izobraževanju. S tem bi se približali večini drugih evropskih držav, ki so to že naredile. Da je Slovenija v tem pogledu na repu Evrope dokazuje šest let stara tabela (Pižorn, spletni dokument, str. 2) iz leta 2005. Ce povzamem: V Sloveniji, Romuniji in Litvi se otroci začnejo učiti tujega jezika pri devetih letih. Kasneje (pri desetih letih) samo še na Slovaškem, Portugalskem in Škotskem. Vse ostale države svojim državljanom nudijo učenje tujega jezika prej: Belgija, Španija, Italija, Avstrija in Finska pri treh letih, pri štirih Luxemburg in Nizozemska, pri petih Češka, Francija in Malta, pri šestih Nemčija, Madžarska, Liechenstein in Norveška, pri sedmih Anglija, Estonija in Švedska in pri osmih letih Turčija in Bolgarija.

Predvsem pa zato, ker v naši raziskavi večina staršev ocenjuje, da so se jezika naučili ravno v času šolanja, kar lahko kaže na uspešnost programov tujih jezikov $\mathrm{v}$ slovenskem izobraževalnem sistemu in seveda enakopravno dostopnost do znanja tujih jezikov vsem državljanom. Ugotavljamo, da se na Notranjskem več kot polovica anketirancev ocenjuje, da so enojezični. Pižorn (spletni dokument, str. 3) pravi, da enojezičnost danes ni več kvaliteta, temveč ovira in celo »nevarnost « družbi napredka, sožitja, medsebojnega razumevanja in spoštovanja: »Jezikoslovci že dolgo časa vedo in nam tudi sporočajo, da sta dvo- in večjezičnost veliko pogostejši obliki kot enojezičnost (Baker \& Prys-Jones 1998; Hamers \& Blanc 2000; Crystal 1987; Dewaele et al. 2003; Ellis 2006).«

\section{LITERATURA}

BRUMEN, Mihaela (2003) Pridobivanje tujega jezika v otroštvu: priročnik za učitelje: teoretična in praktična izhodišča za učitelje tujega jezika $v$ prvem in drugem triletju osnovne šole, Ljubljana: DZS.

BRUMEN, Mihaela (2009) Prednosti učenja tujega jezika v predšolski dobi, V: Pižorn $\mathrm{K}$. (ur.), Učenje in poučevanje dodatnih jezikov v otroštvu. 1. izd. Ljubljana: ZRSŠ, str. 63-70.

BRUMEN, Mihaela (2011) The perception of and motivation for foreign language learning in pre-school, Early Child Development and Care, 181-6, str. 717-732.

BRUMEN, Mihaela/N. ROBNIK (2008) Stališča študentov do učenja in poučevanja tujih jezikov v otroštvu. Skela, J (ur.), Učenje in poučevanje tujih jezikov na Slovenskem: pregled sodobne teorije in prakse, Ljubljana: Tangram: str. 792-802.

Cadre européen commun de référence pour les langues (2000) Apprendre, enseigner, évaluer. Strasbourg: Divisions des politiques linguistiques.

ČOK, Lucija/Janez SKELA/Berta KOGOJ/Cveta RAZDEVŠEK PUČKO (1999) Učenje in poučevanje tujega jezika: smernice za učitelje $v$ drugem triletju osnovne šole, Ljubljana: Pedagoška fakulteta in Koper: Znanstveno-raziskovalno središče RS.

DAGARIN FOJKAR, Mateja (2009) Modeli poučevanja tujega jezika v otroštvu - pregled stanja v Evropi in drugje po svetu, Pižorn, K. (ur.), Učenje in poučevanje dodatnih jezikov v otroštvu, 1. izd. Ljubljana: ZRSŠ, str. 154-176. 
JURIŠEVIČ, Mojca (2009) Zaznavanje pouka tujega jezika v prvem triletju osnovne šole in motiviranost učencev za učenje, Pižorn, K. (ur.), Učenje in poučevanje dodatnih jezikov v otroštvu, 1. izd. Ljubljana: ZRSŠ, str. 97-114.

KRASHEN, Stephen D. (1982) Principles and practice in second language acquisition, Oxford: Pergamon, str. 10-32.

MARJANOVIČ UMEK, Ljubica (2009) Razvoj otroškega govora: učinek poučevanja in učenja tujega/drugega jezika, V: Pižorn, K. (ur.), Učenje in poučevanje dodatnih jezikov v otroštvu, 1. izd. Ljubljana: ZRSŠ, str. 71-79.

MARJANOVIČ UMEK/Urška FEKONJA PEKLAJ (2008) Sodoben vrtec: možnosti za otrokov razvoj in zgodnje učenje, Ljubljana: Znanstvenoraziskovalni inštitut Filozofske fakultete.

McKAY, Penny (2005) Assessing Young Language Learners, Cambridge: University Press.

PINTER, Annamaria (2006) Teaching Young Language Learners, Oxford: University Press.

PIŽORN, Karmen (2008) Učenje dodatnih (tujib) jezikov na zgodnji stopnji - (i)zguba ali prednost? Učenje dodatnib jezikov na zgodnji stopnji - trenutno stanje. Spletni naslov: http://www.zrss.si/projektiess/skladisce/sporazumevanje_v_tujih_jezikih/tuj\%20jezik\%20v\%20prvem\%20triletju/Strokovni\%20\%C4\%8Dlanki\%20 in\%20prevodi/ucenje_dodatnih_jezikov_na_zgodnji_stopnji_karmen_pizorn_2008.pdf

MARENTIČ-POŽARNIK, Barica/L. MAGAJNA/C. PEKLAJ (1995) Izziv raznolikosti, stili spoznavanja, učenja, misljenja, Nova Gorica: Educa.

SKELA, Janez/Mateja DAGARIN FOJKAR (2009) Presek teorij učenja in poučevanja drugega/tujega jezika v otroštvu, Pižorn, K. (ur.), Učenje in poučevanje dodatnih jezikov v otroštvu, 1. izd. Ljubljana: ZRSŠ, str. 26-62.

ŠEČEROV, Neva (2008) Zgodnje učenje tujega jezika: zgled celostnega pristopa $k$ učenju in vrednotenju znanja, Skela, J. (ur.), Učenje in poučevanje tujih jezikov na Slovenskem: pregled sodobne teorije in prakse, Ljubljana: Tangram, str. 594-603.

Internetni vir: http://www.ccl-cca.ca/CCL/Reports/SCAL/2007Archive/SCALStructuredImmersion.htm?Xlanguage $=\mathrm{EN}$

Internetni vir : http://register.consilium.europa.eu/pdf/sl/08/st16/st16207.s108. pdf. Resolucija sveta EU o evropski strategiji za večjezičnost 2008 (sprejeta 21. 11. 2008).

POVZETEK

Stališča staršev na Notranjskem in poglavitni motivacijski dejavniki za vključitev otrok v programe zgodnjega učenja tujega jezika pred otrokovim devetim letom starosti

V prispevku predstavljamo stališča staršev na Notranjskem o sodobnih izhodiščih na področju zgodnjega učenja in poučevanja tujih jezikov in njihov vpliv na odločanje staršev za (ne)vključitev otrok v programe zgodnje poučevanje tujega jezika. Na eni strani 
ugotavljamo slabo seznanjenost staršev s strokovno literaturo in slabo poznavanje aktualnega stanja v Sloveniji in v tujini na področju zgodnjega poučevanja tujih jezikov. Na drugi strani pa njihova pozitivna stališča do zgodnjega učenja tujih jezikov, izjemen občutek za pravilen pristop $\mathrm{k}$ zgodnjemu učenju tujega jezika in predvsem njihovo veliko željo po boljšem poznavanju te teme.

Ključne besede: zgodnje učenje tujih jezikov, motivacija, starši, Notranjska

\section{ABSTRACT}

\section{Parental Attitudes and Motivational Factors in Enrollment of Children in Early Foreign Language Learning in the Notranjska Region}

In this article we present the parents' opinions about the contemporary sources in the field of early foreign language teaching and learning and their influence on the decisions parents make about including/excluding their child into the program of early foreign language learning. We found out, on the one hand, that parents are poorly informed about the current state of early foreign language learning both in Slovenia and abroad. On the other hand, parents reported positive attitudes about early foreign language teaching, a remarkable sense of right approach in early foreign language learning and, above all, their desire to know more about the subject.

Key words: early foreign language learning, motivation, parents, Notranjska region 